\title{
О СОСТОЯНИИ ПРАВОНАРУШЕНИЙ В СФЕРЕ ЛЕСОПОЛЬЗОВАНИЯ И МЕРАХ БОРЬБЫ С НИМИ В ПРИМОРСКОМ КРАЕ
}

\begin{abstract}
Аннотация: Изучена борьба с экологическими правонарушениями, совершаемьх не только значительной частью сельского населения, но должностными лицами и руководителями коммерческих и некоммерческих организаций, имеющих невысокий уровень правосознания. Обращено внимание на высокую латентность, и возникающче в связи с этим трудности в деятельности правоохранительных органов по выявлению виновных лиц и установления, причинённого им ущерба. Сложность вызвана недостаточной материально-финансовой обеспеченностью государственной и общественной природоохранной деятельности, не обеспечивается эффективность контрольнонадзорных мероприятий, отсутствует должный механизма участия общественности в борьбе с экологической преступностью. Состояние, динамику, уровень латентности и другие показатели правонарушений в сфере незаконной рубки лесных насаждений проанализированы по официальнылм и научным источникам, а также статистическим данным полученным лично автором. Положительнымм моментом борьбы с незаконной рубкой лесных насаждений может быть система автоматизированного учета кругльх лесоматериалов и отпуска лесных насаждений. В данную систему необходимо включать информация по всем лесопользователям, получившим право заготовки древесины, а также точные сведения о перевозке леса до пункта переработки, в том числе автотранспорт, объемно-сортиментный состав древесины, грузополучатель, грузоотправитель и другое. Abstract: The author studies the measures against the environmental offences committed by the people in the rural areas, as well as by the officials and heads of commercial and non-commercial organization with low level of legal conscience. The author pays attention to the high level of latent offences, as well as to the appearing difficulties in the activities of the law-enforcement bodies in revealing the guilty persons and entities and establishing the amount of damage caused by them. The difficulty concerns the lack of material and financial guarantees of public and non-governmental environmental activities, there is a lack of efficiency of control and supervision measures, there is no due mechanism for the participation of the general public in fighting environmental crime. The situation, dynamics, level of latent offences and other markers for the offences in the sphere of unlawful wood-cutting in the forests are analyzed by the author based upon official and scientific sources with the use of statistical data collected by the author. The positive moment in fighting unlawful wood-cutting may be the system of automatized reporting of timber and provision of forests. This system should include the information on all those involved in forest management and clear information on transportation of timber to the processing centers (including automobile transportation, amount and quality of timber, receiver and sender of goods, etc.).
\end{abstract} Ключевые слова: Природопользование, латентность, ответственность, незаконная рубка, правонарушения, лес, окружаюшая среда, древесина, леснье хозяйства, преступность.

Keywords: Nature management, latent character, responsibility, illegal wood-cutting, offences, forest, environment, timber, forest enterprises, crime.

M ногие преступления, в том числе и экологические, характеризуется высокой латентностью, а поэтому в официальной статистике по экспертным оценкам отражается только часть совершаемых преступлений данной категории. Общее количество ежегодно возбуждаемых уголовных дел по фактам выявленных преступных деяний в сфере охраны окружающей среды явно не соответствует числу сообщений о них, известных природоохранным и правоохранительным органам ${ }^{1}$.

\footnotetext{
1 Жадан В. Н. Актуальные вопросы криминологической характеристики экологических преступлений // Молодой ученый. 2013. №4. C. 387-393.
}

Анализ состояния надзорной деятельности органов прокуратуры Приморского края за 2013 г. показал, что по количеству нарушений, выявленных в области охраны окружающей среды и природопользования 2997 (-0,6 \% к показателю АППГ), Приморский край занимает 19 место в РФ и 2 место в ДФО, уступая только Хабаровскому краю (3972). Соотношение выявленных нарушений к принятым мерам реагирования составил 1,62 (среднероссийский показатель - 2,11; средний показатель по ДФО - 1,97) ${ }^{2}$. Из всех реги-

\footnotetext{
${ }^{2}$ Справка «Анализ состояния надзорной деятельности органов прокуратуры Приморского края за январь-сентябрь 2013 г.»
} 
DOI: 10.7256/1811-9018.2014.10.13060

При цитировании этой статьи сноска на доі обязательна

\section{Право и политика $10(178) \cdot 2014$}

стрируемых преступлений данной категории по их количеству от наиболее распространенных к менее выявляемым является - незаконная рубка лесных насаждений (ст. 260 УК),

Проведённая в первом полугодии 2014 года масштабная проверка показала, что департаментом лесного хозяйства и Приморским лесничеством не обеспечивается должная эффективность контрольно-надзорных мероприятий. Несмотря на двукратный рост проведённых ими рейдовых мероприятий, органами прокуратуры выявлено боле 700 нарушений закона в деятельности лесозаготовительных организаций и иных лиц, использующих леса. По возбужденным прокурорами делам об административных правонарушениях только в этом году на правонарушителей наложено более 3 миллионов рублей штрафных санкций

Для проведения исследования нами была запрошена статистическая информация за 2014 годы по следующим направлениям:

- о количестве зарегистрированных и раскрытых преступлений по статье 260 УК РФ «Незаконная рубка лесных насаждений», а также выявленных лиц за 2012-2014 г.г.;

- о количестве зарегистрированных и раскрытых преступлений по статье 261 УК РФ «Уничтожение или повреждение лесных насаждений», а также выявленных лиц за 2012-2014 г.г.;

- о количестве зарегистрированных и раскрытых преступлений по статье 191.1. УК РФ «Приобретение, хранение, перевозка, переработка в целях сбыта или сбыт заведомо незаконно заготовленной древесины» за 2014 год;

- о количестве зарегистрированных и раскрытых преступлений по статье 260 УК РФ «Незаконная рубка лесных насаждений» при наличии реальной совокупности с преступлениями, предусмотренными ст. 285 УК РФ «Злоупотребление должностными полномочиями», ст. 286 УК РФ «Превышение должностных полномочий» и ст. 290 УК РФ «Получение взятки»;

- сведения о результатах возмещения материального ущерба и изъятия предметов преступной деятельности по ст.ст. 260, 261 УК РФ;

- сведения о преступлениях, совершенных иностранными гражданами и лицами без гражданства по ст. 260 УК РФ «Незаконная рубка лесных насаждений» за 2013-2014г;

- сведения о количестве лесных преступлений, уголовные дела о которых направлены в суд за 20122013, первое полугодие 2014 года.

Полученная статистическая информация отражена в следующих сведениях.

\section{Сведения по преступлениям ст.260 УК РФ (УМВД России по Приморскому краю) Дата выдачи 08.09.2014}

\begin{tabular}{|l|l|l|l|l|l|l|l|l|l|l|l|l|l|l|l|}
\hline $\begin{array}{l}\text { направлен- } \\
\text { ность }\end{array}$ \\
преступегений
\end{tabular}

\footnotetext{
${ }^{3}$ Доклад прокурора Приморского края С. Бесчастного6 «Итоги работы органов прокуратуры Приморского края в первом полугодии 2014 года // Служу отечеству. № 8 (78). Август 2014 года.
} 
Сведения по преступлениям ст.260 УК РФ, которые соединены в У/Д с преступлениями по ст.285,286,290

Дата выдачи 08.09.2014

\begin{tabular}{|l|l|l|l|l|l|l|}
\hline & \multicolumn{2}{|l|}{ Зарегистрировано преступлений } & \multicolumn{3}{l|}{ Раскрыто преступлений } \\
\hline & 2012 & 2013 & 06 м2014 & 2012 & 2013 & 06 м2014 \\
\hline $\begin{array}{l}\text { Экономическая } \\
\text { направленность }\end{array}$ & & & & 1 & & \\
\hline $\begin{array}{l}\text { Уголовная } \\
\text { направленность }\end{array}$ & & & & & & \\
\hline всего & & & & 1 & & \\
\hline
\end{tabular}

Сведения о нанесении материального ущерба и его возмещении по ст.260 УК РФ Дата выдачи 08.09.2014

\begin{tabular}{|c|c|c|c|c|c|c|c|c|c|}
\hline & \multicolumn{3}{|c|}{$\begin{array}{l}\text { Добровольно погашено } \\
\text { (в тыс.рублей) }\end{array}$} & \multicolumn{3}{|c|}{$\begin{array}{l}\text { Наложен арест на имущество } \\
\text { (в тыс.рублей) }\end{array}$} & \multicolumn{3}{|c|}{$\begin{array}{l}\text { Изъято имущества, денег, } \\
\text { ценностей(в тыс.рублей) }\end{array}$} \\
\hline & 2012 & 2013 & 06м2014 & 2012 & 2013 & 06м2014 & 2012 & 2013 & 06м2014 \\
\hline $\begin{array}{l}\text { Экономическая } \\
\text { направленность }\end{array}$ & & 55 & 326 & 2700 & 9 & - & 627 & 9 & 6 \\
\hline $\begin{array}{l}\text { Уголовная } \\
\text { направленность }\end{array}$ & 942 & 1239 & 1103 & 125 & 394 & 2488 & 428 & 10730 & 1251 \\
\hline всего & 942 & 1294 & 1429 & 2825 & 404 & 2488 & 1056 & 10739 & 1257 \\
\hline
\end{tabular}

Сведения по преступлениям ст.261 УК РФ Дата выдачи 08.09.2014

\begin{tabular}{|l|l|l|l|l|l|l|l|l|l|l|l|l|}
\hline направленность & \multicolumn{3}{l|l}{$\begin{array}{l}\text { Зарегистрировано } \\
\text { преступлений }\end{array}$} & \multicolumn{2}{l|}{ Раскрыто преступлений } & \multicolumn{2}{l|}{ Направлено в суд } & \multicolumn{3}{l|}{ Выявлено лиц } \\
\hline & 2012 & 2013 & $06 \mathrm{~m} 2014$ & 2012 & 2013 & $06 \mathrm{~m} 2014$ & 2012 & 2013 & $06 \mathrm{~m} 2014$ & 2012 & 2013 & $06 \mathrm{~m} 2014$ \\
\hline $\begin{array}{l}\text { Экономическая } \\
\text { направленность }\end{array}$ & & & & & & & & & & & & \\
\hline $\begin{array}{l}\text { Уголовная } \\
\text { направленность }\end{array}$ & 15 & 7 & 35 & 3 & & 1 & 2 & & & 4 & & 1 \\
\hline всего & 15 & 7 & 35 & 3 & & 1 & 2 & & & 4 & 1 \\
\hline
\end{tabular}

Сведения о нанесении материального ущерба и его возмещении по ст.261 УК РФ Дата выдачи 08.09.2014

\begin{tabular}{|l|l|l|l|l|l|l|l|l|l|}
\hline & \multicolumn{3}{|l|}{$\begin{array}{l}\text { Добровольно погашено } \\
\text { (в тыс.рублей) }\end{array}$} & \multicolumn{3}{l|}{$\begin{array}{l}\text { Наложен арест на имущество } \\
\text { (в тыс.рублей) }\end{array}$} & \multicolumn{3}{l}{$\begin{array}{l}\text { Изьято имущества, денег, } \\
\text { ценностей(в тыс.рублей) }\end{array}$} \\
\hline & 2012 & 2013 & 06 м2014 & 2012 & 2013 & 06 м2014 & 2012 & 2013 & 06 м2014 \\
\hline $\begin{array}{l}\text { Экономическая } \\
\text { направленность }\end{array}$ & & & & & & & & & \\
\hline Уголовная направленность & 14 & & & & & & & & \\
\hline всего & 14 & & & & & & & & \\
\hline
\end{tabular}


DOI: $10.7256 / 1811-9018.2014 .10 .13060$

При цитировании этой статьи сноска на dоі обязательна

\section{Право и политика $10(178) \cdot 2014$}

По некоторым данным, латентность незаконных рубок составляет около $99 \%{ }^{4}$, по другим данным около 70-75\%5. Точные объемы и количество совершенных незаконных рубок не известны, не указываются в базе данных Федеральной службы государственной статистики ${ }^{6}$, не дополняются на официальном сайте Федерального агентства лесного хозяйства после первого полугодия 2007 г., , включены в состав экологических и отдельно не выделяются на официальном сайте МВД РФ $\Phi^{8}$ и т.д. Итоги дистанционного мониторинга, проведенного в 2009 г. (982,3 тыс. куб. м), приведены только для рубок, совершенных без разрешительных документов, в то время как подобные рубки являются лишь разновидностью незаконных рубок лесных насаждений9. Анализ статистических данных выявляет тенденцию увеличения количества зарегистрированных экологических преступлений на территории Дальневосточного федерального округа в период 2004-2009 гг ${ }^{10}$.

Проведенный опрос следователей позволил выявить такую негативную тенденцию, как рост латентности этого вида преступлений. Значительное число опрошенных работников правоохранительных органов (83 человека) заявили об увеличении латентности незаконных рубок, большинство респондентов (76 человек) пояснили, что явление латентности незаконных рубок детерминировано ограниченностью организационноштатного, материально-технического обеспечения деятельности сотрудников лесных хозяйств.

${ }^{4}$ Соколов Н.А. Уголовная ответственность за незаконную рубку лесных насаждений : автореф. дис. ... канд. юрид. наук. М., 2007. C. 3 .

5 Жеребкин Г.Н. Ответственность за незаконную рубку лесных насаждений. Анализ нелегальных рубок на Дальнем востоке и методика их расследования: методическое пособие / Г.Н. Жеребкин. Владивосток: WWF России, «Апельсин», 2011. С. 51.

${ }^{6}$ Федеральная служба государственной статистики [Электронный pecypc] : Базы данных. - Режим доступа : http://www.gks.ru/.(дата обращения: 01.09.2014).

${ }^{7}$ Федеральное агентство лесного хозяйства [Электронный ресурс]: Статистика. - Режим доступа : http://www.rosleshoz.gov.ru/activity/ illegal/stat.

${ }^{8}$ Министерство внутренних дел Российской Федерации [Электронный ресурс] : Статистика. - Режим доступа : http:// www.mvd.ru/

9 Рослесхоз [Электронный ресурс] : итоги дистанционного мониторинга незаконных рубок и использования земель лесного фонда в 2009 году. - Режим доступа: http://www.advis.ru/cgi-bin/ new. (дата обращения: 01.09.2014).

${ }^{10}$ Васильева М.A. Криминалистическая характеристика и первоначальный этап расследования преступлений, связанных с незаконной рубкой лесных насаждений (по материалам Дальневосточного региона России). Дис. ... канд. юрид. наук., М. 2014. С. 22.
Обратим внимание, что суммы ущерба от незаконных рубок на территории Дальневосточного федерального округа с каждым годом только увеличивались (в 2012 году он составил порядка 2 млрд. рублей, для сравнения в 2005 году он едва превышал 500 млн. рублей). Так, в Приморском крае в 2008 г. общая сумма ущерба составила 1 млрд. 447 млн. рублей, в 2009 г. - 1 млрд. 626 млн. рублей, в 2010 г. - 1 млрд. 928 млн. рублей ${ }^{11}$. Сумма ущерба зависит от объема рубки и находится с ним в прямой пропорциональности. То есть, в период с 2008 г. до 2010 г. объемы незаконных рубок не снижались, а продолжали расти. (диаграмма 1).

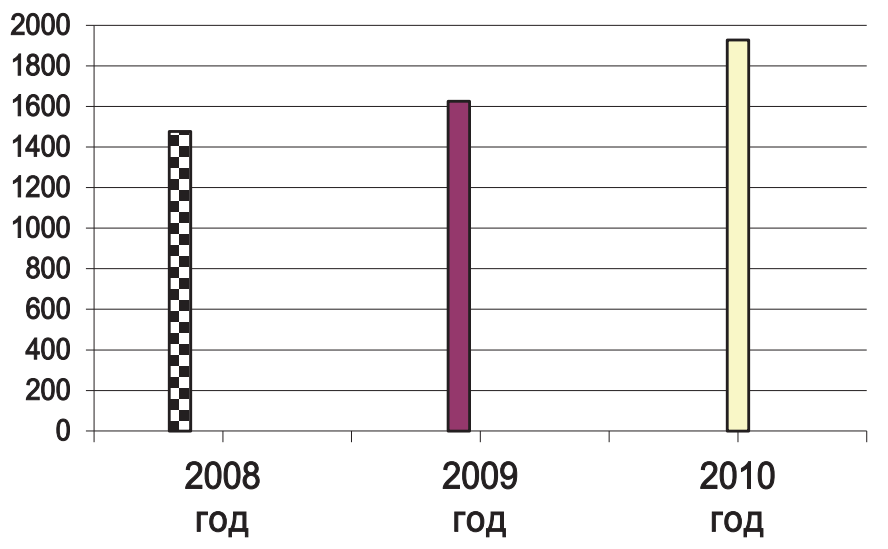

Диаграмма 1. Динамика роста ущчерба от незаконных рубок на территории Дальневосточного федерального округа в период 2008 - 2010 г2. (млн. руб.)

При этом суды в Российской Федерации в большинстве случаев прекращают уголовные дела по ст. 260 УК РФ, по заявлению потерпевшей стороны, поддержанное государственным обвинителем. Анализ уголовных дел, производство по которым прекращено, в связи с примирением сторон, показал, что, как правило, сумма причиненного ущерба и размер соответствующих выплат произведенных виновными в качестве заглаживания вреда, несопоставимы. Соглашаясь на примирение, потерпевшие учитывают материальное положение виновных. Например: Согласно материалам дела Р.Р.Т. возмещено 10000 рублей - квитанция об оплате (л. д. 281). Общая стоимость незаконно срубленных берез составила 462 рубля 67 копеек, сумма причиненного ущерба - 46267 рублей. Другой пример, постановлени-

\footnotetext{
${ }^{11}$ Жеребкин Г.Н. Ответственность за незаконную рубку лесных насаждений. Анализ нелегальных рубок на Дальнем востоке и методика их расследования: методическое пособие / Г.Н. Жеребкин. Владивосток: WWF России, «Апельсин», 2011. С. 56.
} 
ем мирового судьи судебного участка № 2 Тисульского района от 19.11.2007 прекращено уголовное дело в отношении Е. по п. «Г» ч. 2 ст. 260 УК РФ. Общий ущерб от незаконной порубки кедра составил 122413 рублей, стоимость незаконно спиленных деревьев составляет - 2448 рублей 26 копеек, виновным ущерб возмещен в размере 5800 рублей. Таким образом, в обоих случаях сумма возмещенного ущерба больше чем, стоимость незаконно спиленных деревьев (прямой ущерб), но существенно меньше причиненного ущерба.

В то же время имел место случай, когда общий ущерб от незаконной порубки составил 1338673 рубля 50 копеек, прямой ущерб - 60963 рубля 20 копеек, вред, причиненный лесному фонду, возмещен в сумме 26773 рублей 47 копеек, т.е. в 2 раза меньше прямого ущерба (постановление Тисульского районного суда от 13.09.2007 в отношении К. по ч. 3 ст. 260 УК РФ).

Следует отметить, что по двум уголовным делам не усматривается, в каком размере возмещен причиненный ущерб (уголовное дело в отношении С. по ч. 3 ст. 260 УК РФ - постановление мирового судьи судебного участка № 2 Тисульского района от 03.12.2007 и уголовное дел в отношении Ж. по ч. 3 ст. 260 УК РФ - постановление мирового судьи судебного участка № 2 Тисульского района от 19.11.2007). Согласно материалам дела заявление представителя потерпевшего о прекращении уголовного дела содержит указание на возмещение ущерба без указания суммы. Материалы дела квитанций об оплате ущерба не содержат. В судебном заседании размер возмещения вреда, не выяснялся. Кроме того, по одному уголовному делу на момент принятия мировым судьей решения о прекращении производства по делу, в связи с примирением сторон, ущерб возмещен не был (постановление мирового судьи судебного участка $\mathrm{N} 1$ Новокузнецкого района от 20.02.2007 в отношении С.). Принимая такое решение, мировой судья указал, что С. обвиняется в незаконной рубке лесных насаждений в крупном размере, общая сумма причиненного ущерба - 114529 рублей. От представителя потерпевшего Н. поступило заявление с просьбой прекратить уголовное дело в отношении С. за примирением сторон. Государственный обвинитель полагает возможным прекратить уголовное дело, по такому основанию. С. в содеянном раскаялся, совершил преступление небольшой тяжести впервые, примирился с потерпевшим и загладил причиненный вред.

Однако из материалов дела усматривается, что в заявлении представитель потерпевшего просил прекратить уголовное дело в связи с примирением, поскольку С. обязуется оплатить ущерб в размере 35000 рублей в течение 10 дней (стоимость незаконно срубленных берез составила 1145 рублей 29 копеек). После вынесения постановления о прекращении уголовного дела ущерб был возмещен. В материалах дела имеется копия квитанции об оплате указанной суммы в срок ${ }^{12}$.

При этом незаконные рубки лесных насаждений в значительно большем объеме стали осуществляться организованно, профессионально, как правило, на коррупционной основе с чиновниками региональной власти и с использованием современных заготовительно-транспортных средств, приняв огромные масштабы с элементами криминального бизнеса. В свою очередь государства пограничные с Россией, в частности, Китай значительно сократили заготовку собственной лесной древесины, рассчитывая на более дешевое российское сырье, невзирая на его зачастую нелегальное происхождение.

В свете сложившейся обстановки роль и значение правовых способов и инструментов регулирования взаимодействия в области экологии значительно возрастает, в первую очередь, в области лесных отношений. Посредством применения юридической ответственности реализуется целый ряд функций, способствующих исполнению норм уголовного законодательства в области незаконных рубок, в том числе осуществляется стимулирование соблюдения норм права, касающихся окружающей природной среды (стимулирующая функция), возмещается вред природной среде и здоровью человека (компенсационная функция), обеспечивается предупреждение новых преступлений и правонарушений в области экологического права (превентивная функция), достигается наказание лица, виновного в совершении экологического преступления или правонарушения (карательная функция).

Незаконные рубки лежат в основе практически всех иных преступлений, совершаемых в лесной отрасли, поэтому пресечение данных преступлений является приоритетной задачей правоохранительных и контролирующих органов. Работа оперативных подразделений по предотвращению преступных посягательств в данной отрасли осуществляется на огромной территории

\footnotetext{
${ }^{12}$ Обзор Кемеровского областного суда от 12 марта 2008 г. n 0119/152 «Обзор судебной практики по рассмотрению судами Кемеровской области уголовных дел и дел об административных правонарушениях в области охраны окружающей среды и природопользования, а также о рассмотрении судами гражданских дел по искам о взыскании ущерба и другого вреда, причиненного в результате нарушения экологического законодательства». Электронный реcypc. URL: http://www.alppp.ru/court/20-apelljacionnyj-sud/03-2008/ obzor-kemerovskogo-oblastnogo-suda-ot-12-03-2008--01-19152.pdf. (дата обращения 29.08.2014г.)
} 
DOI: $10.7256 / 1811-9018.2014 .10 .13060$

При цитировании этой статьи сноска на доі обязательна

\section{Право и политика $10(178) \cdot 2014$}

(площадь лесного фонда Приморья составляет порядка 12 млн. гектар, из которых 11,3 млн. гектар покрыты лесом) и ее эффективное осуществление силами одной полиции невозможна.

В связи с этим, актуальным становится обмен имеющейся оперативной информацией и проведения совместных профилактических мероприятий с Департаментом лесного хозяйства, Прокуратурой, УФСБ и другими органами власти и управления в рамках Плана декриминализации наиболее высока.

Одной из наиболее эффективных мер противодействия незаконным рубкам, успешно используемой на протяжении последних 10-ти лет, является ежегодное проведение на территории «лесных» районов края специальных оперативно-профилактических мероприятий под условным наименованием «Лес» с участием всех названных служб.

В зимний период 2012-2013 годов на территории Приморского края в ходе мероприятий проверено 678 объектов лесопромышленного комплекса, выявлено 433 факта незаконных рубок, изъято 24 единицы спецтехники, 472 кубометра незаконно заготовленной древесины. Ущерб (с учетом экологического) составил более 550 млн. рублей. За первый квартал 2014 года сведения представлены в таблицах 1 и 2 .

В 2012 году на территории Приморского края выявлено 647 преступлений по фактам совершения незаконных порубок (АППГ - 691). Окончены расследованием уголовные дела по 138 преступлениям (122), из которых 114 направлены в суд (113), к уголовной ответственности привлечено 154 лица (132).

Подразделениями ЭБиПК УМВД России по Приморскому краю выявлено 12 преступлений эконо- оперативным данным (4), привлечено к уголовной ответственности 9 человек (6).

В 2013 года в лесной отрасли подразделениями УМВД России по Приморскому краю выявлено 508 преступлений (АППГ - 511), из них 497 фактов незаконных рубок (АППГ-498), в структуре которых 491 общеуголовной направленности и 6 экономической (АППГ-4). Выявлено 17 преступлений экономической направленности (АППГ - 17), из них 16 следствие по которым обязательно (АППГ - 16). Зарегистрировано 8 тяжких и особо тяжких составов $(A П П Г-6)$ и 9 преступлений совершенных в крупном и особо крупном размере $(А П П Г-7)$. В структуре экономической преступности 6 фактов мошенничества (АППГ-2), 2 должностных преступления (АППГ-3) и 4 коррупционных преступления (АППГ-3).

Если сравнить с Сахалинской областью, то по осуществлению государственного надзора в сфере полномочий Министерством лесного и охотничьего хозяйства Сахалинской области за 2013 год выявлены 63 незаконные рубки деревьев, ущерб, от которых составил 5,8 млн. руб. В следственные органы направлены материалы по 38 случаям незаконной рубки, с общим ущербом 5,7 млн. руб. По 32 из них возбуждены уголовные дела. По остальным не завершены проверки. По 24 незаконным рубкам деревьев, с общим ущербом 40,2 тыс. руб., в отношении нарушителей возбуждены дела об административных правонарушениях. Общая сумма наложенных штрафов - 106,0 тыс. руб.

За нарушения лесохозяйственных требований и договорных условий лесопользователям начислено и предъявлено 1,67 млн. рублей неустоек, из которых 1,03 млн. рублей взыскано (таблица 1$)^{13}$.

Таблииа 1.

Сведения о нарушениях лесного законодательства (незаконная рубка лесных насаждений) в Приморском крае ${ }^{14}$

\begin{tabular}{|c|c|c|c|c|c|c|}
\hline \multirow{2}{*}{ год } & \multicolumn{2}{|c|}{ Число случаев (ед.) } & \multicolumn{2}{|c|}{ Объем лесонарушений $\left(\mathrm{M}^{3}\right)$} & \multicolumn{2}{c|}{ Ущерб в тыс. руб. } \\
\cline { 2 - 7 } & Всего & $\begin{array}{c}\text { в том числе } \\
\text { совершено не } \\
\text { выяленными } \\
\text { нарушителями }\end{array}$ & Всего & $\begin{array}{c}\text { в том числе } \\
\text { совершено не } \\
\text { выявленными } \\
\text { нарушителями }\end{array}$ & $\begin{array}{c}\text { Всего } \\
\text { совершено не } \\
\text { выявленными } \\
\text { нарушителями }\end{array}$ \\
\hline $\begin{array}{c}\text { январь-июнь } \\
2014\end{array}$ & 204 & 144 & 12666 & 8661 & 624807,6 & 474861,2 \\
\hline
\end{tabular}

мической направленности, предварительное следствие по которым обязательно (АППГ - 5), из них 5 тяжких и особо тяжких составов (5), совершенных в крупном и особо крупном размере - 5 (2). Выявлено 3 должностных преступления (0), три факта коммерческого подкупа (0). Раскрыто 16 преступлений (6), в т.ч. 9 по
${ }^{13}$ Итоги работы по осуществлению государственного надзора
в сфере полномочий Министерства за 2013 год. Официальный
сайт Министерство лесного и охотничьего хозяйства Сахалинской
области. Электронный ресурс. URL: http://les.admsakhalin.
ru/?page=768\&div=. (дата обращения 28.08.2014г).
${ }^{14}$ Статистическая отчетность по формам 20-ОИП, 21-ОИП, 22-ОИП,
25-ОИП за 1 квартал 2014 года деятельности лесопромышленного 
DOI: $10.7256 / 1811-9018.2014 .10 .13060$

При цитировании этой статьи сноска на dоі обязательна

Юридический практикум

\begin{tabular}{|c|c|c|c|c|c|c|}
\hline $\begin{array}{c}\text { Январь-март } \\
2014\end{array}$ & 125 & 79 & 8617 & 5850 & 406076,8 & 336999,1 \\
\hline & & & & & & \\
\hline
\end{tabular}

В текущем году в результате применения авиатехники совместно с УФСБ России по Приморскому краю и Департаментом лесного хозяйства установлена масштабная незаконная рубка общим объемом около 150 м. куб., ущерб от которой превысил 14 млн. рублей. В ходе операции изъята древесина (объемом 50 м. куб) и использовавшаяся для незаконной заготовки леса спецтехника (трактор марки ДТ-75). Возбуждено уголовное дело (№ 194908) по ч. 3 ст. 260 УК РФ. Ведется следствие.

Кроме этого, в период проведения операции осуществлено два совместных рейда в «лесные» районы с природоохранной прокуратурой Приморского края и сотрудниками ФСБ России по Приморскому краю. В результате в декабре 2012 года возбуждено уголовное дело по ч. 3 ст. 260 УК РФ в отношении лиц из числа руководства ООО «Ольгалес» по факту осуществления рубки леса сверх установленных объемов. В январе текущего года возбуждено аналогичное уголовное дело в отношении лиц, из числа руководства ОАО «Приморские лесопромышленники».

В целом за 9 месяцев в лесопромышленном комплексе края выявлено 508 преступлений (АППГ - 511), из которых 497 фактов незаконных рубок (АППГ - 498). Расследованы и направлены в суд уголовные дела по 79-ти фактам незаконных рубок (АППГ-95), в результате чего к уголовной ответственности привлечено 103 лица (таблица 2)

Примером являются уголовные дела (№№ $817428 u$ 818128) возбужденные 05 и 06 июня текущего года по материалам сотрудников УМВД России по Приморскому краю по ч. 3 ст. 159 УК РФ в отношении начальника Пластунского участка Тернейского филиала КППК “Приморское ЛХО” Михеева, который получал заработную плату за лиц фактически не работавших на предприятии, подделывая их подписи. Ведется следствие.

В ходе проведения оперативно-розыскных мероприятий, направленных на пресечение преступных посягательств при реализации на территории края краевой целевой программы “Охрана лесов от пожаров в Приморском крае” на 2011 - 2015 годы” (на 2013 год предусмотрено финансирование с сумме 271,6 млн. руб.) 23.08.2013 по оперативным материалам сотрудников УЭБиПК возбуждено уголовное дело (№ 835506) по ч. 1 ст. 285 УК РФ в отношении руководителя филиала КГКУ «Приморское лесничество» Денисова Р.А., который, используя свое служебное положение, с целью создания видимости благоприятной обстановки и эффективности тушения лесных пожаров, а также не введения режима чрезвычайного положения в 200 раз (c 2000га до 10га) занизил площадь лесного пожара при составлении протокола. Ведется следствие.

Необходимо отметить основные причины и условия, способствующие совершению незаконных

Таблица 2.

Количество дел направленных в следственные органы

\begin{tabular}{|c|c|c|c|c|c|}
\hline \multirow{3}{*}{$\begin{array}{c}\text { Наименование } \\
\text { показателя }\end{array}$} & \multirow{3}{*}{ Код строки } & \multicolumn{4}{|c|}{ Направлено дел в следственные органы } \\
\hline & & \multirow[b]{2}{*}{$\begin{array}{l}\text { всего, } \\
\text { шт. }\end{array}$} & \multirow{2}{*}{$\begin{array}{c}\text { из них } \\
\text { отказано, } \\
\text { шт. }\end{array}$} & \multicolumn{2}{|c|}{$\begin{array}{c}\text { из принятых к } \\
\text { расследованию дел }\end{array}$} \\
\hline & & & & $\begin{array}{c}\text { возбуждено уголовных дел, } \\
\text { шт. }\end{array}$ & $\begin{array}{c}\text { привлечено } \\
\text { к уголовной } \\
\text { ответственности, чел. }\end{array}$ \\
\hline A & Б & 13 & 14 & 15 & 16 \\
\hline Лесонарушений, всего & 100 & 127 & 4 & 70 & 5 \\
\hline $\begin{array}{l}\text { в том числе: } \\
\text { незаконная рубка лесных } \\
\text { насаждений }\end{array}$ & 110 & 125 & 4 & 70 & 5 \\
\hline
\end{tabular}

комплекса Приморского края. Официальный сайт Приморского края. [Электронный ресурс]. URL: http://primorsky.ru/authorities/executive-agencies/departments/forestry/statistics.php. (дата обращения: 15.08.2014). 
DOI: $10.7256 / 1811-9018.2014 .10 .13060$

При цитировании этой статьи сноска на доі обязательна

\section{Право и политика $10(178) \cdot 2014$}

рубок на территории края - это бесконтрольный экспорт древесины за рубеж и, прежде всего, в Китай. Стимулирующим фактором преступной деятельности является невозможность привлечения преступников к уголовной ответственности за вывоз незаконно добытой древесины.

В настоящее время обеспечить действенный контроль и проверку законности оборота экспортируемой лесопродукции ни силами ОВД, ни таможенными органами невозможно в связи с тем, что в обязательный пакет внешнеэкономической сделки не входят документы, подтверждающие ее легальность в обороте - для экспортеров-лесопользователей. Это может быть документ департамента лесного хозяйства, для других - договора купли-продажи и товаросопроводительные документы (ранее таким документом являлся лесорубочный билет).

Эта проблема недавно обсуждалась на заседании рабочей группы по противодействию незаконной заготовке древесины в Дальневосточном федеральном округе, участие в котором приняли руководители полиции и подразделений ЭБиПК, а также представители департаментов лесного хозяйства всех субъектов ДФО.

Участники заседания сошлись во мнении, что назрела необходимость разработки правовых основ государственной политики в сфере оборота круглых лесоматериалов. Для этого, в первую очередь, необходимо принятие ряда правовых актов, устанавливающих процессы оборота древесины, в частности, внести дополнения в Таможенный кодекс России для определения документов, необходимых при оформлении древесины на экспорт.

Еще одним решением проблемы бесконтрольной рубки леса может стать положительный опыт борьбы с преступностью в этой отрасли Республики Башкортостан, где в 2007 году внедрена система автоматизированного учета круглых лесоматериалов и отпуска лесных насаждений. В данной системе аккумулируется информация по всем лесопользователям, получившим право заготовки древесины, а также точные сведения о перевозке леса до пункта переработки, в том числе автотранспорт, объемносортиментный состав древесины, грузополучатель, грузоотправитель и другое.

Данная информационная система позволила в течение пяти лет уменьшить число незаконных рубок, совершенных в Республике Башкортостан практически в 2 раза, а объем незаконно срубленной древесины - в 3,4 раза (в 2008 году в республике зарегистрировано 1266 случаев незаконных рубок $c$ суммарным объемом незаконно заготовленной древесины более 23,1 тыс. м3, а в 2012 году - 694 случая с суммарным объемом 6,8 тыс. м3.).

В Приморском крае проект регионального Закона, предусматривающего создание подобной информационной системы контроля был разработан еще в прошлом году, однако, до настоящего времени Думой Приморского края не принят. Принятие данного нормативного акта, а также установка видеокамер значительно оздоровит ситуацию в лесопромышленном комплексе края Приморского края. Положительное воздействие может оказать соблюдение краевого законодательства об обороте древесины, которым установлена внушительная сумма административных штрафов - до пятисот тысяч рублей на юридических лиц.

\section{Библиография:}

1. Жадан В. Н. Актуальные вопросы криминологической характеристики экологических преступлений // Молодой ученый. 2013. №4. С. 387-393.

2. Соколов Н.А. Уголовная ответственность за незаконную рубку лесных насаждений: автореф. дис. .... канд. юрид. наук. M., 2007. C.

3. Жеребкин Г.Н. Ответственность за незаконную рубку лесных насаждений. Анализ нелегальных рубок на Дальнем востоке и методика их расследования: методическое пособие / Г.Н. Жеребкин. Владивосток: WWF России, «Апельсин», 2011. С. 51.

4. Васильева М.А. Криминалистическая характеристика и первоначальный этап расследования преступлений, связанных с незаконной рубкой лесных насаждений (по материалам Дальневосточного региона России). Дис. ... канд. юрид. наук., M. 2014. C. 22.

5. Куракин А.В. Компетенция полиции в сфере реализации законодательства об административных правонарушениях // NB: Административное право и практика администрирования. - 2013. - 4. - C. 28-48. DOI: 10.7256/2306-9945.2013.4.8841. URL: http://www.e-notabene.ru/al/article_8841.html

6. Волков А.М., Лютягина Е.А. Судебные способы разрешения административных споров в области природопользования // Административное и муниципальное право. - 2012. - 7. - С. 81-88.

7. Д.Б. Савчишкин Административная ответственность как средство обеспечения информационной безопасности. // Административное и муниципальное право. - 2011. - 6. - С. 55-63.

8. И. М. Мацкевич, В. Н. Орлов Третий международный круглый стол Союза криминалистов и криминологов по темам: «Проблемы борьбы с преступностью в странах СНГ», «Современное уголовное законодательство: проблемы, тенденции 
DOI: $10.7256 / 1811-9018.2014 .10 .13060$

При цитировании этой статьи сноска на доі обязательна

Юридический практикум

и пути модернизации» (Республика Казахстан, г. Астана, г. Алматы, 1-6 мая 2013 г.) // Союз криминалистов и криминологов. - 2013. - 1. - С. 19-21.

9. Полевщикова Ю.А., Акбаров О.М. Оценка лесного покрова Волжского лесничества Республики Марий Эл методами дистанционного зондирования // NB: Кибернетика и программирование. - 2013. - № 4. - C.59-65. DOI: 10.7256/23064196.2013.4.9333. URL: http://e-notabene.ru/kp/article_9333.html

10. Ипатов Ю.А., Кревецкий А.В., Шмакин В.О. Проектирование распределенной наземной системы мониторинга за лесными пожарами // NB: Кибернетика и программирование. - 2013. - № 2. - C.20-28. DOI: 10.7256/2306-4196.2013.2.8309. URL: http://e-notabene.ru/kp/article_8309.html

11. Аверина К.Н. Экологическая политика ЕС в области охраны лесов // NB: Международное право. - 2013. - № 3. - C.36-51. DOI: 10.7256/2306-9899.2013.3.402. URL: http://e-notabene.ru/wl/article_402.html

12. К. Н. Аверина. Основные направления международной политики в сфере охраны лесов // Международное право и международные организации / International Law and International Organizations. - 2011. - № 2

\section{References (transliterated):}

1. Zhadan V. N. Aktual'nye voprosy kriminologicheskoi kharakteristiki ekologicheskikh prestuplenii // Molodoi uchenyi. 2013. №4. S. 387-393.

2. Sokolov N.A. Ugolovnaya otvetstvennost' za nezakonnuyu rubku lesnykh nasazhdenii : avtoref. dis. ... kand. yurid. nauk. M., 2007. S.

3. Zherebkin G.N. Otvetstvennost' za nezakonnuyu rubku lesnykh nasazhdenii. Analiz nelegal'nykh rubok na Dal'nem vostoke i metodika ikh rassledovaniya: metodicheskoe posobie / G.N. Zherebkin. Vladivostok: WWF Rossii, «Apel'sin», 2011. S. 51.

4. Vasil'eva M.A. Kriminalisticheskaya kharakteristika i pervonachal'nyi etap rassledovaniya prestuplenii, svyazannykh s nezakonnoi rubkoi lesnykh nasazhdenii (po materialam Dal'nevostochnogo regiona Rossii). Dis. ... kand. yurid. nauk., M. 2014 . S. 22.

5. Kurakin A.V. Kompetentsiya politsii v sfere realizatsii zakonodatel'stva ob administrativnykh pravonarusheniyakh // NB: Administrativnoe pravo i praktika administrirovaniya. - 2013. - 4. - C. 28-48. DOI: 10.7256/2306-9945.2013.4.8841. URL: http:// www.e-notabene.ru/al/article 8841.html

6. Volkov A.M., Lyutyagina E.A. Sudebnye sposoby razresheniya administrativnykh sporov v oblasti prirodopol'zovaniya // Administrativnoe i munitsipal'noe pravo. - 2012. - 7. - C. 81-88.

7. D.B. Savchishkin Administrativnaya otvetstvennost' kak sredstvo obespecheniya informatsionnoi bezopasnosti. // Administrativnoe i munitsipal'noe pravo. - 2011. - 6. - C. 55-63.

8. I. M. Matskevich, V. N. Orlov Tretii mezhdunarodnyi kruglyi stol Soyuza kriminalistov i kriminologov po temam: «Problemy bor'by s prestupnost'yu v stranakh SNG», «Sovremennoe ugolovnoe zakonodatel'stvo: problemy, tendentsii i puti modernizatsii» (Respublika Kazakhstan, g. Astana, g. Almaty, 1-6 maya 2013 g.) // Soyuz kriminalistov i kriminologov. - 2013. - 1. - C. 19-21.

9. Polevshchikova Yu.A., Akbarov O.M. Otsenka lesnogo pokrova Volzhskogo lesnichestva Respubliki Marii El metodami distantsionnogo zondirovaniya // NB: Kibernetika i programmirovanie. - 2013. - № 4. - S.59-65. DOI: 10.7256/2306-4196.2013.4.9333. URL: http://e-notabene.ru/kp/article_9333.html

10. Ipatov Yu.A., Krevetskii A.V., Shmakin V.O. Proektirovanie raspredelennoi nazemnoi sistemy monitoringa za lesnymi pozharami // NB: Kibernetika i programmirovanie. - 2013. - № 2. - S.20-28. DOI: 10.7256/2306-4196.2013.2.8309. URL: http://e-notabene. $\mathrm{ru} / \mathrm{kp} /$ article_8309.html

11. Averina K.N. Ekologicheskaya politika ES v oblasti okhrany lesov // NB: Mezhdunarodnoe pravo. - 2013. - № 3. - S.36-51. DOI: 10.7256/2306-9899.2013.3.402. URL: http://e-notabene.ru/wl/article_402.html

12. K. N. Averina. Osnovnye napravleniya mezhdunarodnoi politiki v sfere okhrany lesov// Mezhdunarodnoe pravo i mezhdunarodnye organizatsii / International Law and International Organizations. - 2011. - № 2 